\title{
REAKTUALISASI HUKUM ISLAM \\ DI INDONESIA DALAM PROSPEK
}

Oleh : Moh. S. Rahman

\begin{abstract}
ABSTRAK
Hukum Islam adalah hukum buat Islam. Artinya hukum Islam berkeduduk-an sebagai pedoman bagi umat Islam dalam beramal baik berupa amal ibadah mahdah maupun ghairu manda.

Hukum Islam yang merupa-kan wahyu Tuhan yang ditekskan dalam bentuk ayat Al Quran dan matan Hadits Nabi Muhammad SAW bersifat terbuka untuk direaktulisasikan yakni diitjtihadi guna mengawal dan memandu dinamika hidup umat Islam.

Kondisi sosial budaya Islam Indonesia dari masa ke masa mulai sebelum pemerintah kolonial Belanda sampai masa kemerdekaan bahkan sampai masa apapun istilahnya reaktulisasi terhadap hukum Islam demikian perlu.

Tulisan ini menggugah para cendikiawan Islam untuk selalu terpanggil menelaah hukum Islam agar selalu actual sebagai way of life.

Kata kunci : Reaktulisasi, Prospek, dan Hukum Islam.
\end{abstract}

\section{Pendahuluan}

Bahwa pada waktu sebelum pe- merintahan Hindia Belanda hukum Islam telah mempunyai peranan yang kuat dan mendapat kedudukan yang penting dan luas dalam masyarakat dan negara, sebagaimana yang diakui dalam catatancatatan baik di luar negeri maupun dalam negeri di Kordova Spanyol, Papakan

Cirebon dan tambo-tambo adat di Indonesia .

Dalam periode pertama pemerintah Hindia Belanda berkat pengaruh Carel Frederic van der Winter, Solomon Keyzer dan Ch. Van den Berg, seperti tertuang dalam Stbl. No. 2 kedudukan hukum Islam mempunyai eksistensi yang luas seperti diatur dalam Stbl. 1882 No. 152 tentang Pengadilan Agama. Baru kemudian dengan Stbl. 1929 No. 447 Pasal 234 ayat (2) I.S. hukum Islam baru dinyatakan berlaku apabila telah diterima oleh hukum adat, sejalan dengan itu wewenang peradilan agama dibatasi yang semula termasuk hadhanah, 
curatele dan waris mal waris, hanya berwenang sepanjang masalah nikah, talak dan rujuk saja lagi (Stbl. 1937 No. 116)

Setelah Indonesia merdeka hukum Islam kembali memegang perananpenting berdasarkan Mukad-dimah dan pasal 29 UUD 1945. Seterusnya dikeluarkannya Undangundang Nomor 14 tahun 1970, dimana peradilan agama sederajat dengan peradilan umum demikian juga ditambah diperkuat dengan Undang-undang Nomor 1 tahun 1974. Hal ini menurut Sayuti Thalib kebalikan dari teori resepsi, yaitu hukum adat baru berlaku apabila diterima oleh hukm Islam. Dan hukum Islam harus berdasarkan Al-Quran, tetapi amat sayang sekali hanya dengan Surat Edaran Mahkama Agung tanggal 20 Agustus 1075 kembali peradilan agama seperti dalam suasana teori resepsi.' Alhamdulillah dengan ditetapkannya Undang-undang Nomor 7 tahun 1989 tentang peradilan agama dan kompilasi hukum Islam dengan Instruksi Presiden RI Nomor 1 tahun 1991, hukum Islam telah mendapat tempat tersendiri dalam Negara Republik Indonesia walaupun berada dalam bidang hukum perkawinan, kewarisan dan perwakafan.

Dari uraian diatas dapat ditarik suatu kesimpulan yang menjadi pokok permasalahan dari makalah ini adalah bagaimana reaktualisasi hukum Islam dalam sorotan?

\section{Hukum Islam dan Harapan Masa Depan}

Sejarah umat Islam di Indonesia pada hakekatnya adalah sosok dari bangsa, karena jumlah umat Islam yang mayoritas, dominan, seharusnya menentu- kan pola pikir dan pola pembentukan hukum bangsa Indonesia.

Islam sebagai salah satu agama di Indonesia telah meletakkan pelataran nasionalisme guna menentang penjajah yang akhirnya menghasilkan kemerdekaan Indonesia pada tnaggal 17 Agustus 1945.

Paradigma sejarah umat Islam memasuki tahap baru dengan momentum terus yang berlanjut ampai sekarang ini. Dan ketika itu format baru sejarah Indonesia dilukiskan. Dan bagaimana tempat Islam dan umatnya dalam lukisan itu? Dan bagaimana pula kesadaran hukum umat Islam dalam sejarah itu. Dalam momentum menyambut hari Proklamasi kemerdekaan Indonesia. misalnya, pantaskah kita mempermasalahkan sejarah dan hukum umat Islam Indonesia terutama dalam hubungan dengan sejarah resmi khusus dibidang hukum Islam. Ditambah pula dengan kemajuan teknologi dan komunikasi yang 
demikian pesat akhir-akhir ini, demikian juga penemuan baru dalam tehnologi komunikasi tinggi umum, menjadikan dunia ini seakan-akan begitu sempit. Kemajuan tehnologi komunikasi telah melintasi jarak dan waktu, yang menimbulkan pengaruhdalam setiap aspek kehidupan manusia muslim. Khusus pada bidang hukum, lebih khusus lagi hukum Islam perlu kiranya mendapat perhatian serius dalam hubungan timbal balik antar individu, masyarakat, dan negara serta hubungan dengan Allah rabbul 'alamin.

Walaupun secara lahiriah tampak dewasa ini semakin banyak negara berpenduduk Islam yang melaksanakan Islamisasi secara konsekwen.

Paling akhir dapat dilihat adalah Sudan yang dipimpin oleh Presiden Gaffar Numeiri, sejak tahun 1984 memberlakukan hukum Islam melaksanakan sistem ekonomi Islam, merekrut tokohtokoh terkemuka Islam ke dalam pe- merintahan dan lain-lain.

Perkembangan ini men-cemaskan EE ropa dan Barat pada umumnya. Karena ii tu mereka berusaha meninggalkan proses Islamisasi Sudan dengan berbagai cara, menunda bantuan untuk pelaksanaan pembangunan proyek-proyek patungan dan lain-lain.

Tidak kurang pula pers Barat dengan gencar mendiskreditkan Numeiri dengan proses Islamisasi-nya. Seperti halnya pada waktu penjajahan Belanda di Indonesia, politik hukum Islam untuk menciptakan hukum yang berdiri sendiri telah merupakan suatu kenyataan dalam masyarakat.

Keraj aan-keraj aan Islam yang pernah berdiri di Indonesia mempraktekkan Islam baik sebagai agama maupun sebagai hukum dalam wilayah kekuasaan masing-masing. Sampai-sampai di zaman VOC. Hukum Islam itu di-akui sebagai hukum sebagaimana terkenal dalam compendium freijer. Disamping itu dibuat pula kumpulan hukum Semarang, Bone, Gowa (Makassar).'

Pada abad 19 Politik Pemerintah Hindia Belanda sendiri sangat berharap segera dapat menghilangkan pengaruh Islam dari sebagian besar orang Indonesia dengan berbagai cara diantaranya melalui kristenisasi. Harapan ini sebagian besar didasarkan kepada anggapan tentang superioritas agama Kristen terhadap agama Islam dan sebagian lagi didasarkan pada kepercayaan bahwa sifat sinkretis agama Islam di pedesaan Jawa akan memudahkan orang Islam akan di Kristen-kan dari pada mereka yang berada di negaranegara muslim lainnya. ${ }^{3}$ 
Akibat dari pada usaha dan politik Pemerintah Hendia Belanda tersebut di atas sangat terkesan dan mempengaruhi nilai kehidupan umat Islam dan hokum Islam di Indonesia.

Walaupun secara teoritis hukum Islam menjadi dasar bagi semua aspek dan bagi setiap pemeluk agama Islam, namun karena pengaruh kehidupan sosial, bu-daya, politik dan ekonomi, dalam kenyata-annya hukum Islam itu masih memper-juangkan tempatnya dalam masyarakat, yang lebih ironis lagi memperjuangkan tempatnya dalam masyarakat Islam itu sendiri.

Tinjauan tentang pembaharu-an atau perubahan hukum perlu kita melihat pada perkembangan hukum yang terjadi di masa lampau seperti sering dikatakan orang.

Hari ini adalah perkembangan hari kemarin dan hari ini pula merupakan dasar bagi hari kemudian. Apa yang terjadi dulu adalah merupakan akar-akar yang terjadi sekarang dan akan menentukan yang terjadi di masa yang akan datang. ${ }^{4}$

Revolusi dihasilkan oleh Week of Islamic Law, yaitu penemuan yang diadakan oleh cabang dari orientalis status pada tanggal 7 Juli 1951, sebelum menghadapi International Congres of Conparative Law. Pertemuan mana dihadiri oleh Profesor-profesor terkemuka dalam ilmu hukum baik dari Timur maupun dari Barat yang dipimpin oleh Profesor Milliot dari Universitas Paris. Dari hasil pembicaraan dalam sidang tersebut, nyata telah terbukti bahwa prinsipprinsip hukum Islam mempunyai nilainilai yang tak dapat diartikan lagi dan bahwa berbagai mazhab yang ada dalam lingkungan besar sistim hukum itu mengandung suatu kenyataan pemikiran hukum dan keyakinan tehnik yang mengagumkan, yang memberi kemungkinan kepada hukum ini memenuhi semua kebutuhan penyesuaianpenyesuaian yang dituntut oleh hidup moderen.'

Apakah hukum Islam itu dapat berperan dalam membangun ekonomi masyarakat Indonesia? Apakah hukum Islam itu adaptability of Islamic Law, merupakan pertanyaan pula dalam dekade men-datang. ${ }^{6}$

Ada pendapat yang menyata-kan bahwa perubahan/pembahasan pada nilainilai hukum Islam me-rupakan persoalan besar yang dihadapi oleh umat Islam, setidak-tidaknya sebagai era kehidupan baru bagi hukum Islam yang akan membebaskan diri dari kebekuan yang mendekati kematian. 
Sedang dipihak lain dalam menghadapi adanya perubahan sosial dan politik, maka hukum adalah merupakan suatu bidang yang secara langsung terkena oleh adanya perubahan itu.

A.A. Fyzee menilai hukum Islam itu sama dengan Camon Law of Islam, yakni keseluruhan dari pemerintah Tuhan. Tiap perintah Tuhan dinamakan hukum. Hukum dan tafsirnya sangat mudah untuk dipahami dan hukum Islam meliputi semua tingkah laku manusia. Oleh karena itu hukum Islam tidaklah dapat dikatakan sebagai hukum dalam artian moderen dalam akan, tetapi hanya mengandung pedoman-pedoman moral.'

Secara singkat dapat dikata-kan bahwa Islam adalah suatu agama yang sangat menonjolkan aspek hukum dalam aj arannya.

Hukum Islam dapat berubah sesuai dengan perkembangan tehnologi super moderen, melalui ijtihad para faqih. Disamping ijtihad pada akhirnya toh karakteristik asli dari bangsa Indonesia akan sangat menentukan bagaimana hukumnya itu dijadikan sehari-hari. ${ }^{8}$

Islam bertujuan Baldatun thayyibatun wa rabbun ghafuur, suatu masyarakat yang baik adil dan makmur dengan jiwa penduduknya yang meme-gang nilai-nilai hukum dan spiritual yang tinggi. Hukum Islam adalah realisasi dari tujuan atau hasil pokok utama itu.

Ibadat dan perinciannya tidak dapat diruabah akan tetapi hukum muamalah dan halhal yang ber-hubungan dengan masyarakat dapat diubah dengan perinciannya, selama konsepsi tersebut dapat diubah dengan perinciannya, selama konsep-si tersebut dipegang teguh, maka dapatlah kiranya hukum Islam diperguna-kan sebaik-baiknya dalam masyarakat abad ke 20 yang sangat merasakan keguncangan yang di-sebabkan oleh per-benturan kepentingan. Dengan menggali sumber-sumber yang terdapat dalam hukum Islam tidak berlebih-lebihan agaknya menurut Prof. Dr. H.M. Rasyidi mantan Menteri Agama RI. Menyatakan bahwa kita melakukan amalan dari pada sila Ketuhanan Yang Maha Esa.

Bahwa hukuim Islam disamping mewujudkan kebahagiaan materil, moril dan spiritual atau Baldatun thayyibatun wa rabbun ghafuur yaitu negara yang baik dan diridhai oleh Allah Swt. dalam pelaksanaannya tidak luput dari interplay dengan situasi.

Moh. Nasir dalam bukunya Islam dan Akal Merdeka, mengemukakan bahwa salah satu dari tiang-tiang agama, ajaran junjungan Islam Muhammad Saw., yang penting ialah menghargai akal manusia dan memperlindunginya dari, pada tindakan-tindakan yang mungkin dilakukan orang atas nikmat Allah yang tak ternilai. Junjungan Islam menempatkan akal pada tempatnya yang terhormat, menjadikan akal itu sebagai salah satu alat untuk 
mengetahui Tuhan. Bertebaran dalam Al-Qur'an beberapa pertanyaan- pertanyaan untuk memikat perhatian menyeluruh mempergunakan fikiran mendorong manusia supaya menjalankan akalnya untuk berfikir baik politik, sosiologis maupun philosophis. ...Apakah kamu tidak memikirkannya (al-An'am:50) ${ }^{11}$...Maka tidaklah kamu berfikir? (alBagarah:44) ${ }^{12}$...Sesungguhnya telah Kami jelaskan tanda-tanda kebesaran (Kami) ke-pada orang-orang yang menetahui (al-An'am:98) ${ }^{13}$ Sesungguhnya. Kami telah menjelaskan tandatanda kebesaran (Kami) kepada orang-orang yang mengetahui. (al-An'am:97).

Dari penggalan-penggalan ayat tersebut diatas dapatlah dipahami adanya perintah dari Sang Pencipta kepada orang yang mempergunakan akalnya untuk sekurang-kurangnya memikirkan menge-nai kemaslahatan hidupnya khususnya lagi menyangkut masalah hukum.

Dalam Pembukaan UUD 1945, misalnya, Tuhan diakui sebagai pemberi "berkah dan rahmah" lebih jauh lagi Pasal 4 ayat (1) Undang-undang Nomor 14 tahun 1970 tentang Pokok-pokok Ke- kuasan Kehakiman juga menyatakan bah- wa "Peradilan dilakukan demi keadilan berdasarkan Ketuhanan Yang Maha Esa"

Dengan demikian berarti bahwa sistem hukum berdasarkan Pancasila itu adalah sistim hukum yang ber-Ketuhanan Yang Maha Esa, hal ini berarti pula bahwa hukum Islam itu sesuai dengan Pancasila, karena hukum Islam pada pokoknya hukum yang berasal dari Tuhan Yang Maha Esa.

Meskipum hukum Islam itu berasal dari Tuhan Yang Maha Esa bukan berasal dari masyarakat dimana manusia itu berkembang namun tidak harus diartikan bahwa hukum Islam itu tidak berkembang dan tidak berubah sesuai dengan kebutuhan masyarakat dimana masyarakat itu hidup.

Bahwa pola-pola etis dari kaidah- kaidah dalam Al-quran cukup luas memberikan dorongan kepada hukum moderen dan memungkinkan adanya variasi dalam penafsiran sesuai dengan kebutuhan menurut kebutuhan ruang dan waktu.

Atas dasar itulah dapat disimpulkan bahwa baik dari sudut ilmu politik, sosiologis maupun filosofis, hukum Islam itu cukup praktis, realistis dan mampu menjawab tantangan masa lalu, kini dan masa datang dengan landasan dan keunikan way of life yang berdasarkan kepada perintah Allah S wt.

Justru karena itu amat tepatlah pula kiranya dalam kesempatan ini disampaikan bahwa ijtihad dapat pula berfungsi sebagai aspek pengubah hukum. 


\section{Penutup}

Pada bagian penutup ini penulis akan mengemukakan beberapa kesimpulan berdasarkan uraian-uraian yang telah dikemuka-kan sebelumnya yaitu sebagai berikut.

1. Sistim hukum yang berlaku di Indonesia adalah sistim hukum yang sesuai dengan Pancasila dimana Pancasila itu mempunyai sistim yang berKetuhanan Yang Maha Esa.

2. Hukum Islam itu berdasarkan kepada aturan Tuhan Yang Maha Esa.

3. Pemberlakuan hukum Islam di Indonesia telah mengalami beberapa kurun waktu dan pada masa sekarang ini hukum Islam cukup berperan dalam pembentu-kan sistim hukum nasional. Hal ini dapat dilihat antara lain Undang-undang Nomor 14 tahun 1970 tentang Pokok-pokok Kekuasaan Kehakiman, Undang-undang Nomor 1 tahun 1974 tentang Perkawinan dan Undang-undang Nomor 7 tahun 1989 tentang Peradilan Agama.

4. Prospek pengembangan hukum Islam di Indonesia yang sesuai dengan adanya budaya ke-Indonesia-an sangat terbuka karena sifat dari hukum Islam itu yang fleksibel dan dibukanya peluang eleh Al-Quran untuk menggunakan akal fikiran. 


\section{CATATAN KAKI :}

1. Sayuti Thalib, Resepsio a contrairo (Hubungan Hukum Adat Dengan Hukum Islam), (Jakarta, Academika, 1980), h. 9.

2. Muhammad Daud Ali, Kedudukan Hukum Islam dalam Sistem Hukum nasional di Indonesia, (Jakarta, Hukum dan Pembangunan, Fakultas Hukum UI. No.2, 1997), h. 105.

3. Ibid.,h. 102.

4. Asikin Z. Kusumaatmadja, Kuliah Politik Hukum pada Fakultas Pasca Sarjana UI, (Jakarta, Kuliah ke I Semester II, 1984), h. 32

5. Said Ramadhan, Islamic Law, its Scope and Equality, (London, Mc Millian Limited, 1961), h. 30.

6. Charles Himawan, Bagaimana Fungsi Hukum di Indonesia dalam Dekade Mendatang, (Jakarta, Kuliah pada Fakultas Pasca Sarjana UI, 1984), h.

7. Mas'ud Muhammad Khalid, Islamic Legal Philosophy a Study of Abu Ishak the Shatibies Life and Thought, (Pakistan, Islamic Research Institute Islamad, 1977) h.l.

8. Sutjipto Rahardjo, Hukum dan Pembangunan, (Bandung, Alumni, 1980), h. 10

9. H. M. Rasyidi, Keutamaan Hukum Islam, (Jakarta, Bulan Bintang, 1971), h. 7.

10. Moh. Nasir, Islam dan Akal Merdeka, (Jakarta, Bulan Bintang, t.th.), h. 35.

11. Departemen Agama RI, Al-Qur'an dan Terjemahannya, (Proyek Pengadaan

12. Kitab Suci Al-Qur'an Departemen Agama RI., Pelita III/Tahun V/1983), h. 194.

13. Ibid., h. 16.

14. Ibid., h. 203

15. Ibid. 